Канд. техн. наук К.В. Крячко, магістри О.М. Шалімова, С.В. Кабанець

Cand. of techn. sciences K. Kriachko, masters $O$. Shalimova, E. Kabanets

\title{
МІНІМІЗАЦІЯ ЕКСПЛУАТАЦІЙНИХ ВИТРАТ ПРИ УДОСКОНАЛЕННІ ТЕХНІЧНОГО СТАНУ СОРТУВАЛЬНИХ СТАНЦЙ
}

\section{MINIMIZATION OF RUNNING EXPENSES IS AT THE IMPROVEMENT OF THE TECHNICAL STATE OF THE SORTING STATIONS}

\author{
Представив д-р техн. наук, професор О.М. Огар
}

Вступ. Одним 3 вирішальних завдань залізничного транспорту протягом останніх років $\epsilon$ підвищення ефективності функціонування засобів транспорту за рахунок мінімізації експлуатаційних витрат як на шляху транспортування вантажів, так i в процесі обслуговування рухомого складу на технічних станціях, особливо на сортувальних. Але прогресуюче старіння основних фондів при відсутності державної підтримки інноваційного розвитку галузі та недосконалості законодавчої бази у частині залучення інвестицій не дає можливості вирішення даного завдання на належному рівні.

Загальний ступінь зносу основних фондів опорних сортувальних станцій перевищує $60 \%$. Застаріле обладнання сортувальних пристроїв, верхньої будови станційних колій, пристроїв вагонного господарства вимагає додаткових експлуатаційних витрат на їх утримання в робочому стані.

Постановка завдання. Якщо для обслуговування транзитного i місцевого вагонопотоків у 1991 році необхідно було мати 51 сортувальну станцію, то на початок 2013 року стоїть питання про скорочення їх кількості з 36 до 30, а при обгрунтуванні - до 25, у зв'язку зі спадом обсягів перевезень у три рази. Із загальної кількості призначень плану формування в сортувальних парках тільки $15 \%$ наскрізних, а решта - місцеві. Це викликає неефективне використання корисної довжини, збільшуючи експлуатаційні витрати на їх поточний ремонт. У цілому колійний розвиток сортувальних станцій не відповідає обсягам переробки і потребує необхідного обслуговування.

Аналіз досліджень і публікацій. Значний внесок у дослідження цих питань зробили такі вчені: Данько М.I., Огар О.М., Берестов I.В., Яновський П.О., Шиш В.О., Шаповал А.В. У результаті проведеного аналізу було встановлено, що в сучасних умовах дане питання вимагає додаткових досліджень.

Визначення мети та завдання дослідження. Основним завданням $\epsilon$ визначення потужності основних пристроїв станції з метою приведення їх до існуючих обсягів роботи.

Основний матеріал. Аналіз основних показників роботи залізниць України, згідно 3 [1], показав, що обсяг навантажених і відправлених вагонів 31991 
по 2001 роки зменшився на $65 \%$, але за останні 10 років спостерігається щорічний приріст з незначними коливаннями 2-3\%. Отже, початкове технічне оснащення повинне бути приведене у відповідність до сучасних обсягів роботи.

Основним пристроєм на сортувальній станції, від результатів роботи якого залежить більшість кількісних i якісних показників, $\epsilon$ сортувальна гірка. Згідно 3 [2], потужність гірки визначається обсягом вагонопотоку 3 переробкою або кількістю колій у сортувальному парку. Звичайно, гірки великої та підвищеної потужності обладнувалися новими системами механізації та автоматизації, сортувальні парки проектувалися за типовими проектами 3 гірковими горловинами на 32 i більше колій. Крім цього, 11 сортувальних станцій є двосторонніми, які повинні були переробляти понад 6 тис. ваг/доб.

На сьогодні у зв'язку зі скороченням обсягів роботи усі сортувальні станції повинні бути перебудовані, а більша частина 3 них - реконструйована, тому для визначення необхідних коштів у цілому по Укрзалізниці на технічне переоснащення слід розробити перспективні плани організаційно-технічних заходів для кожної сортувальної станції. У першу чергу слід розглядати організаційні заходи, що пов'язані із удосконаленням технології роботи у кожній підсистемі станції і вимагають найменших грошових вкладень.

Серед технічних спочатку планують заходи для демонтування окремих пристроїв (колій та стрілочних переводів в основних парках, насувних, спускних та обхідних колій на гірці, з'єднувальних колій, витяжних колій формування у хвостовій горловині сортувального парку, окремих паралельних ходів у горловинах приймально-відправних парків, одиничних опор контактної мережі та опор точкового освітлення після демонтування певних колій у парках).

Але перед цим проводяться хронометражні встановлюються розрахункові значення інтенсивностей виконання відповідних операцій у парках та на гірці для визначення достатності пристроїв, що залишаються після демонтування.

Крім цього, виконуються прогнозні розрахунки обсягів роботи станції і якщо протягом 5 років буде виникати необхідність збільшення колійного розвитку до сучасних розмірів, то замість демонтування здійснюється консервація.

Особливо капіталоємним $є$ технічне обладнання сортувальних пристроїв, тому прогнозування обсягів переробки необхідно проводити на період до 10 років. При сталому їх зменшенні можливо здійснювати демонтування окремих елементів гірки.

Аналіз роботи залізниць України за останні 10 років (рис. 1) показав, що найбільші обсяги навантаження i відправлення вагонів виконуються на Донецькій залізниці, тому для прикладу розглянута одна із потужних сортувальних станцій цього регіону - Ясинувата.

У свій час двостороння сортувальна станція Ясинувата переробляла понад 10 тис. ваг/доб, на ній упроваджувалися найновіші технології сортувального процесу, Західна гірка була обладнана автоматизованою системою управління процесом розпуску составів, новими типами вагонних уповільнювачів, гірковою автоматичною локомотивною сигналізацією. Але зі зменшенням обсягів роботи нові системи були законсервовані, інтенсивність використання інших пристроїв стала неефективною, що вимагало приведення їх потужності у відповідність до сучасних обсягів роботи.

У зв'язку 3 цим на станції були проведені статистичні дослідження за 20022012 роки, встановлені середньодобові обсяги переробки на кожній гірці, проаналізована динаміка зміни кількості та потужності призначень за планом формування у кожній сортувальній системі, визначено рівень навантаження колійного розвитку в основних парках. 


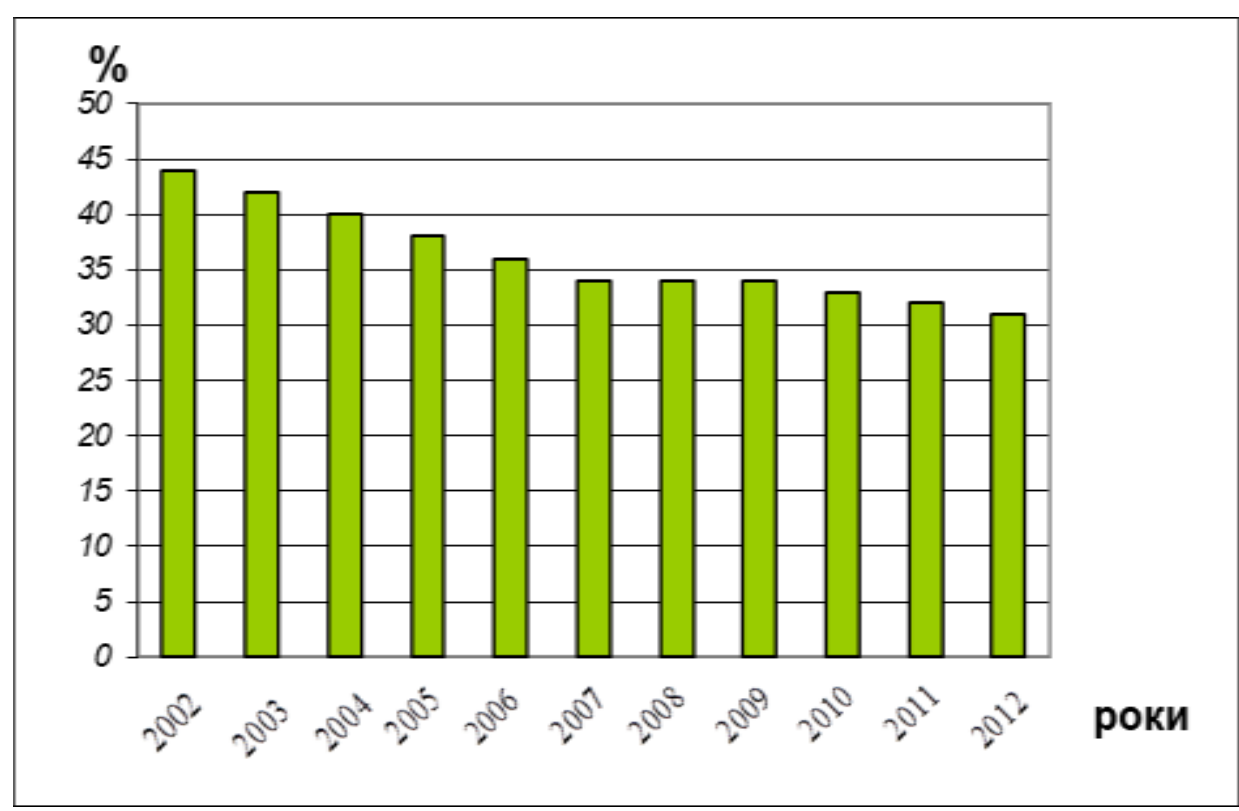

Рис. 1. Середньодобове навантаження вагонів на Донецькій залізниці у відсотках до загального на Укрзалізниці

Результати аналізу показали, що обсяги вагонопотоку з переробкою у Західній сортувальній системі склали від 1962 до 2371, а у Східній - від 2356 до 2747 ваг/доб (рис. 2).
Як видно з рис. 2, найбільший обсяг переробки на Західній гірці спостерігався у 2004 році (2371 ваг/доб), а на Східній - у 2007 році (2747 ваг/доб). Згідно з [2], такі обсяги переробки характерні для гірок середньої потужності з кількістю колій у сортувальному парку від 17 до 29.

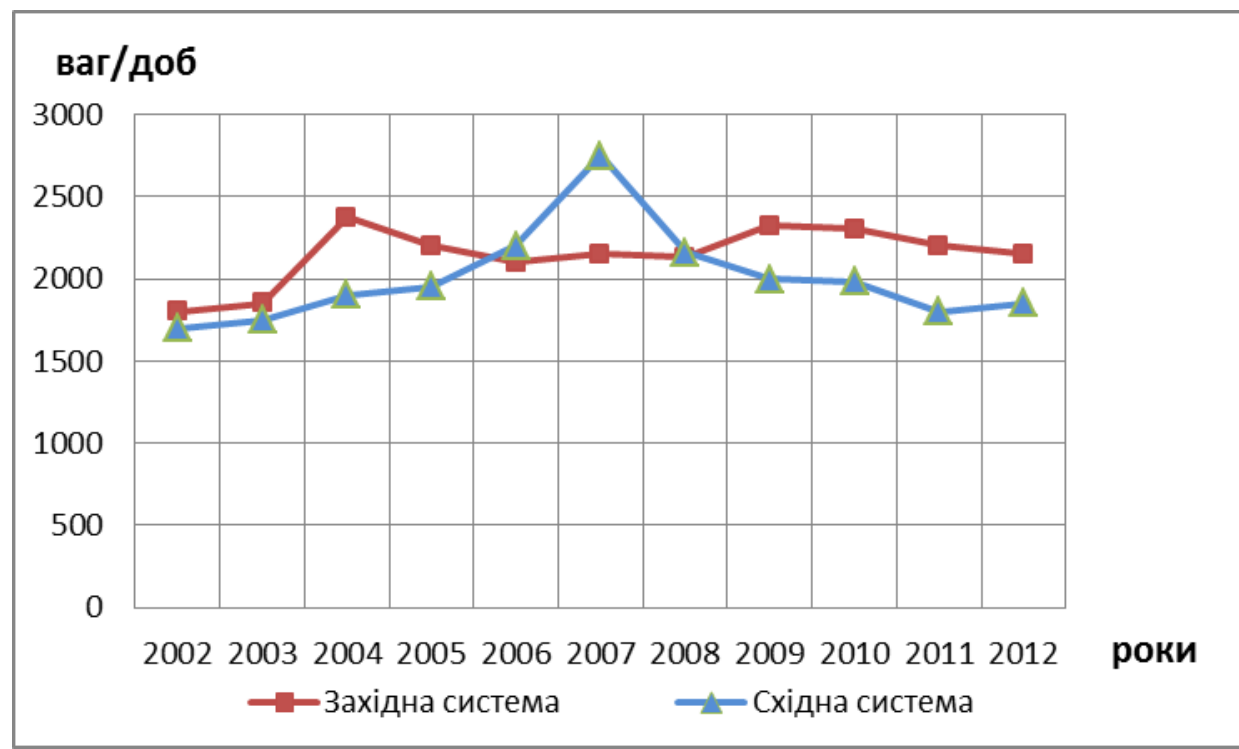

Рис. 2. Середньодобові вагонопотоки з переробкою в Західній і Східній сортувальних системах станції Ясинувата протягом 2002 - 2012 pp. 
Дослідження розподілу середньодобової кількості вагонів за період спостереження показало, що математичне очікування на Західній сортувальній гірці склало 2167 ваг/доб, а з урахуванням трьох середньоквадратичних відхилень 2416 ваг/доб (рис. 3), а на Східній гірці відповідно - 2552 і 2930 ваг/доб (рис. 4).

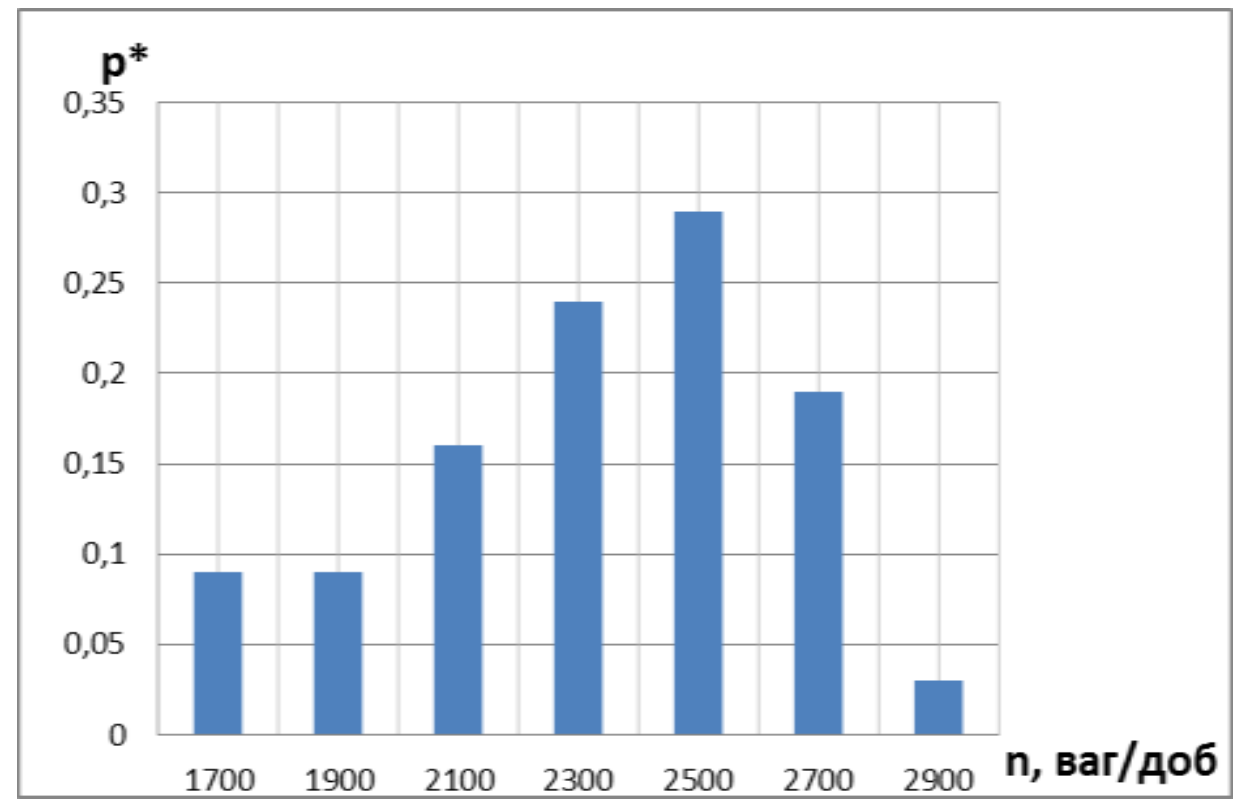

Рис. 3. Гістограма розподілу середньодобової кількості вагонів 3 переробкою на Західній гірці за період 2002 - 2012 рр.

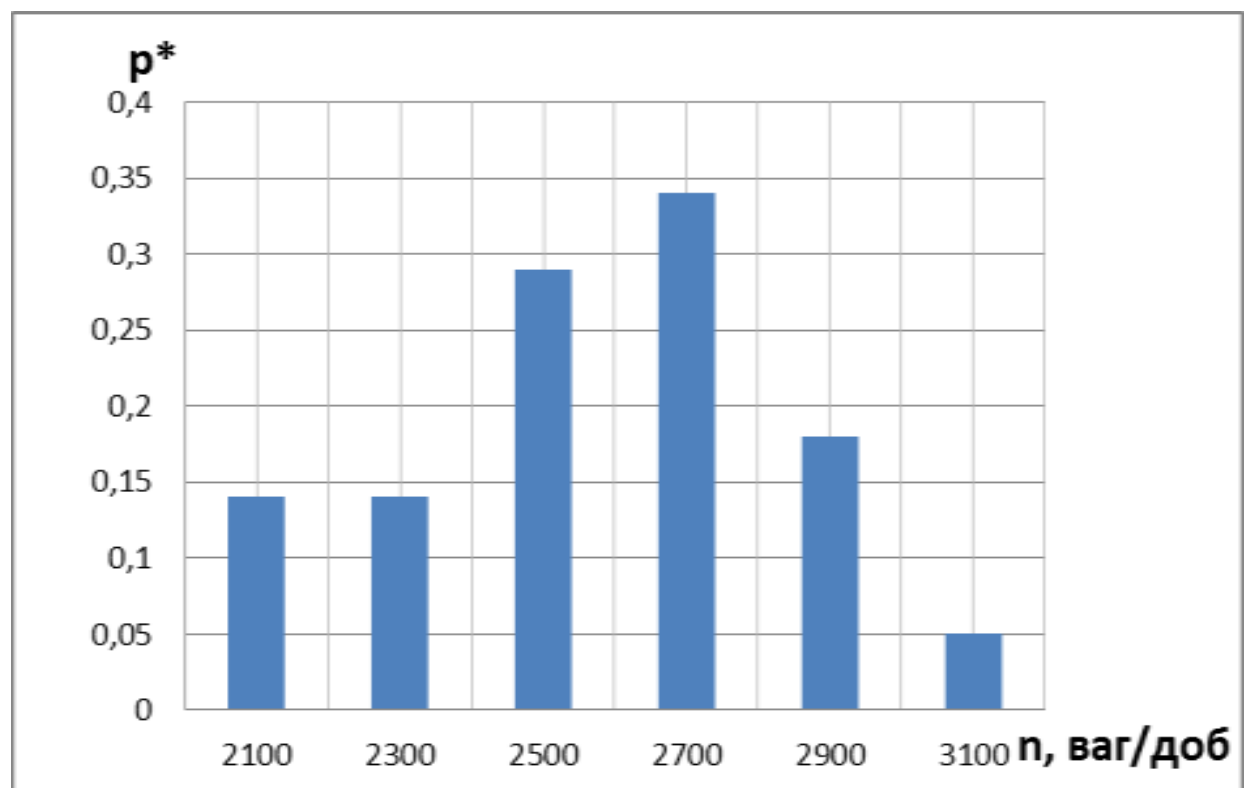

Рис. 4. Гістограма розподілу середньодобової кількості вагонів з переробкою на Східній гірці за період 2002 - 2012 рр.

Крім цього, було встановлено, що за період з 2002 по 2012 рік кількість призначень за планом формування зменши- лась у Західному сортувальному парку в 1,8 разу, а у Східному - в 2,1 разу [3]. 
Це дозволяє зробити висновок про можливість зменшення кількості колій у Західному сортувальному парку на 4 загальною довжиною 3847 м, щорічні експлуатаційні витрати на утримання яких складають 692,5 тис. грн. Крім цього демонтується 8 стрілочних переводів: 4 одиночних симетричних марки 1/6 - №12, 15, 43, 46 та 4 звичайних марки 1/9 - №587, 589, 629, 631, на утримання яких щорічно витрачається відповідно 12 та 16,6 тис. грн.

На кожній колії також демонтується по три секції вагонних уповільнювачів типу ВНУ-2, приведені щорічні експлуатаційні витрати на утримання яких складають 61,2 тис. грн, отже, на чотирьох коліях витрати будуть 244,8 тис. грн.

У Східному сортувальному парку кількість колій може бути зменшена на 8 загальною довжиною 4974 м, 3 урахуванням з'єднувальних елементів. Щорічні експлуатаційні витрати на утри-мання цих колій складають 895,3 тис. грн. При цьому демонтується 15 стрілочних переводів: 7 одиничних симетричних марки 1/6 №118，120，122，124，126，194，198; 7 звичайних марки 1/9 - № 191, 207, 211, 215, 217, 221, 223 та один перехресний стрілочний перевід марки 1/9 - № 187/189 3 переукладанням його на звичайний лівосторонній стрілочний перевід марки 1/9 - №187, на утримання яких щорічно витрачається відповідно 21; 28,7 та 5,6 тис. грн.

Одночасно 3 цим на кожній колії демонтується вагонний уповільнювач типу КНП-5, сумарні приведені щорічні експлуатаційні витрати на утримання яких складають 297,6 тис. грн. На 5 коліях демонтується по одному башмакоскидачу, загальні щорічні експлуатаційні витрати на їх утримання складають 6,8 тис. грн.

Отже, щорічний економічний ефект від скорочення експлуатаційних витрат при зменшенні кількості сортувальних колій в обох сортувальних системах та демонтуванні відповідних пристроїв на цих коліях може складати 2,22 млн грн.

У подальших дослідженнях передбачається здійснювати аналіз використання колійного розвитку приймально-відправних парків 3 метою приведення його у відповідність до сучасних обсягів роботи станції.

Висновки. У зв'язку зі скороченням загальних обсягів перевезень, інтенсивність використання основних пристроїв на залізничних станціях на даний час не відповідає їх розрахунковій потужності, це викликає значні додаткові щорічні експлуатаційні витрати та збільшує собівартість переробки вагонів.

Для підвищення ефективності роботи станцій слід систематично виконувати дослідження ритмічності функціонування як окремих складових, так і сортувальної системи в цілому, 3 метою виявлення раціонального завантаження колійного розвитку, сортувальних пристроїв, маневрових засобів у відповідності до реальних обсягів роботи, що може дати можливість суттєвого скорочення експлуатаційних витрат.

\section{Список літератури}

1. Довідник основних показників роботи залізниць України (2001-2011 роки) [Текст]. К.: Укрзалізниця, 2012. - 53 с.

2. Правила и нормы проектирования сортировочных устройств на железных дорогах Союза ССР [Текст]. - М.: Транспорт, 1992. - 105 с.

3. Порядок направления вагонопотоков и организация их в грузовые поезда на железных дорогах Украины на 2011-2012 гг. (план формирования поездов) [Текст].- К.: Государственная администрация железнодорожного транспорта Украины, 2010. - 667 с.

Ключові слова: вагони 3 переробкою, сортувальний парк, щорічні експлуатаційні витрати. 


\section{Анотації}

Дається аналіз зміни обсягів переробки вагонів на залізницях України і на станції Ясинувата протягом 2002-2012 рр. Розроблено пропозиції щодо раціонального зменшення кількості колій у сортувальних парках Західної та Східної систем станції Ясинувата. Визначено можливий економічний ефект від приведення колійного розвитку до необхідного відповідно до сучасних обсягів роботи станції.

Дается анализ изменения объемов переработки на железных дорогах Украины на станции Ясиноватая за период 2002-2012 гг. Разработаны предложения по рациональному сокращению числа путей в сортировочных парках Западной и Восточной систем станции Ясиноватая. Определен возможный экономический эффект от приведения путевого развития к необходимому в соответствии с современными объемами работы станции.

The analysis of change of volumes of processing is given on the railways of Ukraine at the station of Yasinovataya for period of 2002-2012 years. Developed suggestion on rational reduction of number of ways in the sorting parks of the Western and East systems of the station of Yasinovataya. A possible economic effect is certain from bringing the ground development over to required in accordance with the modern volumes of work of the station. 